\title{
Gram-Negative Coccobacillus
}

National Cancer Institute

\section{Source}

National Cancer Institute. Gram-Negative Coccobacillus. NCI Thesaurus. Code C122319.

Any bacteria with a shape between that of a sphere and a rod that contains low levels of peptidoglycan in its cell wall and stains pink with the Gram staining technique. 